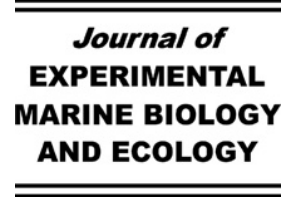

Journal of Experimental Marine Biology and Ecology 345 (2007) 119-128

www.elsevier.com/locate/jembe

\title{
Effects of food diversity on diatom selection by harpacticoid copepods
}

\author{
Marisa Wyckmans ${ }^{\mathrm{a}}$, Victor A. Chepurnov ${ }^{\mathrm{b}}$, Ann Vanreusel ${ }^{\mathrm{a}}$, Marleen De Troch $^{\mathrm{a}, *}$ \\ ${ }^{a}$ Ghent University, Biology Department, Marine Biology Section, Campus Sterre, Krijgslaan 281-S8, B-9000 Gent, Belgium \\ ${ }^{\mathrm{b}}$ Ghent University, Biology Department, Protistology and Aquatic Ecology, Campus Sterre, Krijgslaan 281-S8, B-9000 Gent, Belgium
}

Received 13 October 2006; received in revised form 14 February 2007; accepted 15 February 2007

\begin{abstract}
The diversity of species assemblages which occupy a basal position in the trophic pyramid (typically unicellular algae in aquatic environments) is known to influence the interaction with organisms of higher trophic levels. A laboratory feeding experiment was conducted with cultures of three benthic diatom species (Navicula phyllepta, Grammatophora marina and Cylindrotheca closterium) as primary producers and three harpacticoid copepod species (Harpacticus obscurus, Paramphiascella fulvofasciata and Tigriopus brevicornis) as grazers to evaluate the effects of food diversity (and concomitant food availability) on grazing selectivity. This kind of selectivity experiments is singular for benthic harpacticoid copepods as so far, information on food selection of harpacticoids is scarce.

Uptake of a unispecific food source by a single copepod species decreased as food diversity (and concomitant overall food concentration) increased. All three consumers reacted similarly to changing food diversity, but exhibited strong species-specific responses to food identity i.e. which diatom was added was crucial. Irrespective of level of food diversity, H. obscurus took up high amounts of G. marina, whereas both P. fulvofasciata and T. brevicornis preferred C. closterium when given the choice between different diatoms. As for zooplanktonic taxa, this experiment showed that in lower benthic marine food webs both prey organisms (primary producers) and grazers play a very specific role. Diversity of food and its identity are of critical importance at the base of the trophic pyramid, influencing trophic transfer from primary producers over grazers to higher trophic levels.
\end{abstract}

(C) 2007 Elsevier B.V. All rights reserved.

Keywords: Diatoms; Food choice; Food diversity; Food identity; Harpacticoid copepods

\section{Introduction}

Benthic meiofauna constitutes an important component of marine benthic food webs, both as producers (Gee, 1989) and consumers (Montagna, 1995). Harpacticoid copepods (Crustacea) are an important part of this meiobenthos throughout the world and are known to feed on a wide variety of food sources (see Hicks and

\footnotetext{
* Corresponding author. Tel.: +32 9 2648520; fax: +32 92648598 .

E-mail address: marleen.detroch@ugent.be (M. De Troch).
}

Coull, 1983 for review). Although harpacticoids are rarely the dominant taxon in marine sediments, they are known to be the primary food source for bottom or phytal feeding juvenile and small fish. As harpacticooids are important grazers on primary production, they represent an important link between microalgal primary production and higher trophic levels (e.g. Coull, 1990; De Troch et al., 1998; Turner, 2004; Andersen et al., 2005).

In general, many factors interact to determine patterns of prey use by predators, but two are fundamental 
(Wainwright, 1994). First, an environmental factor, only food items that are physically available can be eaten. The second factor is the consumer's effectiveness, since only food items that the consumer is able to locate, capture, handle and digest can be included in the diet (Wainwright, 1994). When searching for food, predators (including herbivores) may encounter a variety of prey items, differing in size, digestibility, accessibility and so on. Each encountered prey item will have a certain 'prey value', dependent on the assimilated energy yield and the energy spent while searching for and handling the prey item (Hughes, 1980). According to the optimal foraging theory, a consumer is assumed to choose the diet which maximizes net energy intake (Charnov, 1976; Hughes, 1980). Furthermore, it has been shown that predators (invertebrate mesograzers e.g. amphipods, isopods, gastropods) may feed at random when prey are in short supply, but may become selective when certain prey are abundant (e.g. Stephens and Krebs, 1986; Cruz-Rivera and Hay, 2000: amphipods; Aberle et al., 2005: isopod and gastropod). For meiofaunal grazers, however, food selectivity is far from well known.

As harpacticoids consume a wide variety of food sources, the question rises whether they feed at random, ingesting food particles as these are encountered, or whether they select specific food items to meet energetic requirements (nutritional quality of the food) or because certain food items are easier to access (food morphology, size). So far, studies on copepod feeding strategies have mainly focused on pelagic systems (e.g. DeMott, 1989; Irigoien et al., 2000; Sommer et al., 2000; Tackx et al., 2003). It has been shown for pelagic copepods (mainly Calanoida) that food selection not only depends on food particle size (Sommer et al., 2000), but that they can discriminate between similar-sized food particles because of chemical properties ('taste', DeMott, 1988).

For harpacticoids, choice of a particular food resource was first demonstrated convincingly by Vanden Berghe and Bergmans (1981). They found Tisbe furcata to have a clear preference for bacteria while two sibling species showed a generalized or indiscriminate selectivity. Several later studies have supported these findings, showing a great variability in food selection by harpacticoid copepods (e.g. Rieper, 1982; Carman and Thistle, 1985; Decho, 1986; Pace and Carman, 1996; Buffan-Dubau and Carman, 2000). Recently a few studies have addressed the importance of food particle size (De Troch et al., 2006) and food concentration (De Troch et al., 2007) on food selectivity in harpacticoid copepod species. So far, these aspects of food selectivity have only been tested by using strains of a single diatom species.
In the present study, the effect of food diversity on diatom selection (rather than total uptake) by harpacticoid copepods was investigated by means of prelabeled diatoms. Harpacticus obscurus, Paramphiascella fulvofasciata and Tigriopus brevicornis were fed on diets composed of three different diatom species that were selected in view of their different size and shape. The diatoms used here (Navicula phyllepta, Grammatophora marina and Cylindrotheca closterium) may therefore also have a different 'prey value'. Special attention was drawn to the effect of increasing food diversity on the uptake of $N$. phyllepta as this diatom has been shown to be a good food resource for harpacticoids (e.g. Sellner, 1976; Nilsson, 1987). This study aimed to test how harpacticoids react in an environment with different food sources or the other way around, an environment impoverished in food choice. Prey switching behavior (i.e. changes in prey selection according to the availability of alternative prey) has been demonstrated for the planktonic copepod Acartia tonsa (Kiorboe et al., 1996) and a variety of other grazers (Cruz-Rivera and Hay, 2000; Goecker and Kåll, 2003; Aberle et al., 2005). All these studies however, are restricted to only one level of food diversity and information on benthic copepods is still lacking.

Here, the effect of food diversity per se was tested. Therefore, experiments with different levels of food diversity (i.e. 1-diatom, 2-diatoms and 3-diatoms treatments) were designed to test whether copepods select other diatoms or switch diet when offered the choice between one, two or three different foods. Furthermore, the effect of diatom identity on food selection within each diversity level was evaluated.

\section{Materials and methods}

The effect of food diversity on food choice was investigated by feeding copepods with different combinations of diatoms. In each combination one diatom species was labeled with the stable isotope ${ }^{13} \mathrm{C}$ (see further) to trace the uptake of this particular diatom and to measure food selectivity (uptake of a particular food source) rather than total food uptake. Grouping the treatments that have the same labeled diatom allowed to evaluate diversity effects on the uptake of this diatom. In addition, treatments were grouped according to their level of food diversity (i.e. 1-diatom, 2-diatoms and 3diatoms treatments) to test for identity effects on diatom uptake.

Clonal cultures of three pennate benthic diatom species (N. phyllepta, G. marina and C. closterium) were isolated from the North Sea and grown in $f / 2$ medium 
(artificial seawater with additional nutrients, Guillard, 1975). Prior to the experiment, all three were enriched with ${ }^{13} \mathrm{C}$ by replacing $\mathrm{NaH}^{12} \mathrm{CO}_{3}$ with $\mathrm{NaH}^{13} \mathrm{CO}_{3}$ in the $\mathrm{f} 2$ medium. Resulting isotope signatures $\left({ }^{13} \mathrm{C}\right)$ were $-3 \%$ and $15419 \%$ (N. phyllepta), $-17 \%$ and $22973 \%$ (G. marina) and $-12 \%$ and $14324 \%$ (C. closterium) for untreated and ${ }^{13} \mathrm{C}$ enriched cultures, respectively. These diatoms were selected for their differences in cell shape (Fig. 1, see also Table 2 in Hillebrand et al., 1999). In addition G. marina formed long cell chains (zig-zag colonies) (Fig. 1). Including this colonial diatom allowed us to test whether selection occur at the level of life forms rather than at the level of individual cells.

Biovolume of diatom cells was calculated following Hillebrand et al. (1999); the necessary linear dimensions were taken from digital photographs of the cells (Leitz Diaplan microscope, OlympusDP50 camera). Average biovolumes of $N$. phyllepta and C. closterium cells proved to be almost identical, $322.93 \mu^{3}$ and $312.34 \mu^{3}$, respectively. The volume of $G$. marina cells was calculated to be c. four times higher in comparison to the other two diatoms. Based on these calculations, the copepods were offered proportionally lower number of $G$. marina cells to make all the treatments (within one diversity level) equal in terms of biovolume of the food supplied (see Table 1). As a consequence of keeping biovolume comparable within treatments of each diversity level instead of remaining total biovolume constant among diversity levels, increasing diversity (by adding diatom species) inevitably implies an increased food availability (see also Discussion).

The grazers selected for the experiment were three harpacticoid species from intertidal environments: H. obscurus (family Harpacticidae, north-coast of France, brown alga Fucus vesiculosus), P. fulvofasciata (family Diosaccidae, Germany, intertidal mudflats) and T. brevicornis (family Harpacticidae, France, rock
Table 1

An overview of the combinations and numbers of cells used in the experiment

\begin{tabular}{|c|c|c|c|c|}
\hline \multirow[b]{2}{*}{ Treatment } & \multicolumn{3}{|c|}{ Diatom species } & \multirow[t]{2}{*}{ Diversity level } \\
\hline & $\begin{array}{l}N . \\
\text { phyllepta }\end{array}$ & $\begin{array}{l}\text { G. } \\
\text { marina }\end{array}$ & $\begin{array}{l}\text { C. } \\
\text { closterium }\end{array}$ & \\
\hline$\left(*={ }^{13} \mathrm{C}\right.$ labeled $)$ & $\mathrm{N}$ & G & $\mathrm{C}$ & \\
\hline $\mathrm{N}^{*}$ & $1 \times 10^{6}$ & & & 1 \\
\hline $\mathrm{N}^{*} \mathrm{G}$ & $1 \times 10^{6}$ & $0.25 \times 10^{6}$ & & 2 \\
\hline $\mathrm{NG}^{*}$ & $1 \times 10^{6}$ & $0.25 \times 10^{6}$ & & 2 \\
\hline $\mathrm{N}^{*} \mathrm{C}$ & $1 \times 10^{6}$ & & $1 \times 10^{6}$ & 2 \\
\hline $\mathrm{NC}^{*}$ & $1 \times 10^{6}$ & & $1 \times 10^{6}$ & 2 \\
\hline $\mathrm{N}^{*} \mathrm{GC}$ & $1 \times 10^{6}$ & $0.25 \times 10^{6}$ & $1 \times 10^{6}$ & 3 \\
\hline $\mathrm{NG}^{*} \mathrm{C}$ & $1 \times 10^{6}$ & $0.25 \times 10^{6}$ & $1 \times 10^{6}$ & 3 \\
\hline NGC* & $1 \times 10^{6}$ & $0.25 \times 10^{6}$ & $1 \times 10^{6}$ & 3 \\
\hline
\end{tabular}

Food density used (number of cells) was based on counts of diatom cells in faecal pellets (De Troch and Ólafsson, unpublished).

pools). The test organisms can be ranked in size as follows $T$. brevicornis (c. $850 \mu \mathrm{m})>P$. fulvofasciata (c. $780 \mu \mathrm{m})>$ H. obscurus $($ c. $550 \mu \mathrm{m})($ De Troch et al., 2006). Prior to transfer into the experimental units, copepods were sorted from stock laboratory cultures and starved overnight. Experimental units were small Petri plates (diameter $=5.2 \mathrm{~cm}$, effective surface area $=$ $21.2 \mathrm{~cm}^{2}$ ) filled up with c. $15 \mathrm{ml}$ of artificial seawater. To obtain a minimum of $15 \mu \mathrm{g} \mathrm{C}$ in copepod tissue per species for carbon isotope analysis, 20 individuals of H. obscurus and P. fulvofasciata and 8 individuals of T. brevicornis (the largest among the three harpacticoids) were used, one copepod species per experimental unit. All cultures and experimental units were kept in a temperature-controlled room at $15-18{ }^{\circ} \mathrm{C}$ with a photoperiod of $12 \mathrm{~h}$ light $/ 12 \mathrm{~h}$ dark.

The experiment consisted of 8 treatments and an initial measurement (at $T_{0}$, at the start of the experiment) was carried out in triplicate, for each of the three copepod

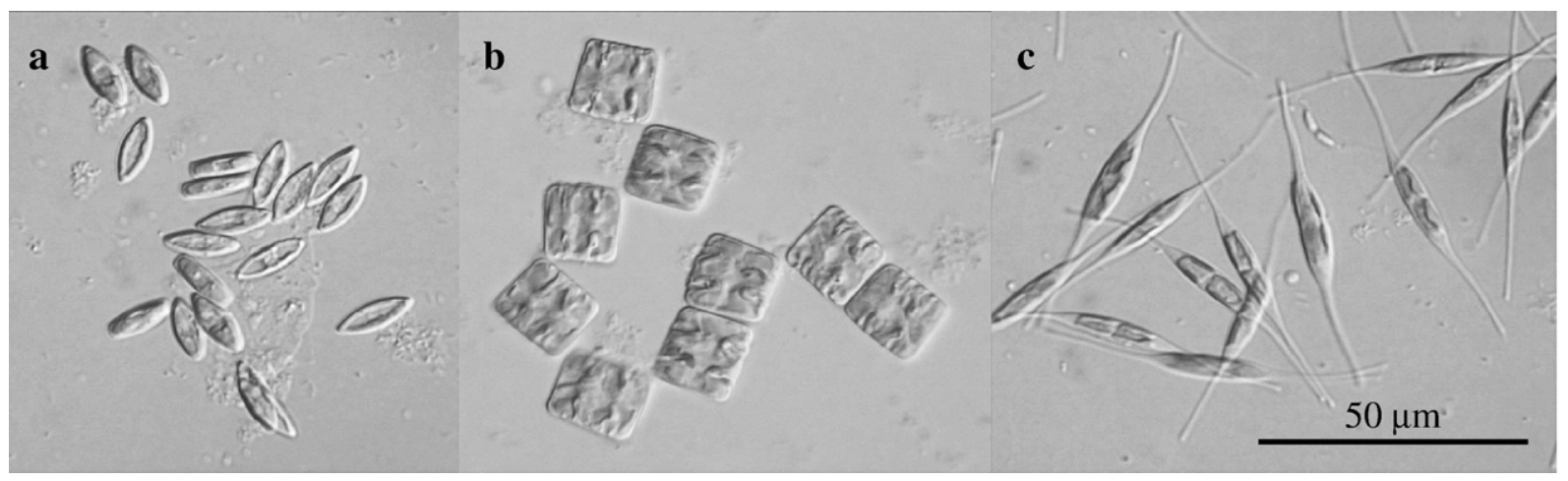

Fig. 1. Diatoms used in the experiment: (a) Navicula phyllepta, (b) Grammatophora marina and (c) Cylindrotheca closterium. 
Uptake Navicula phyllepta
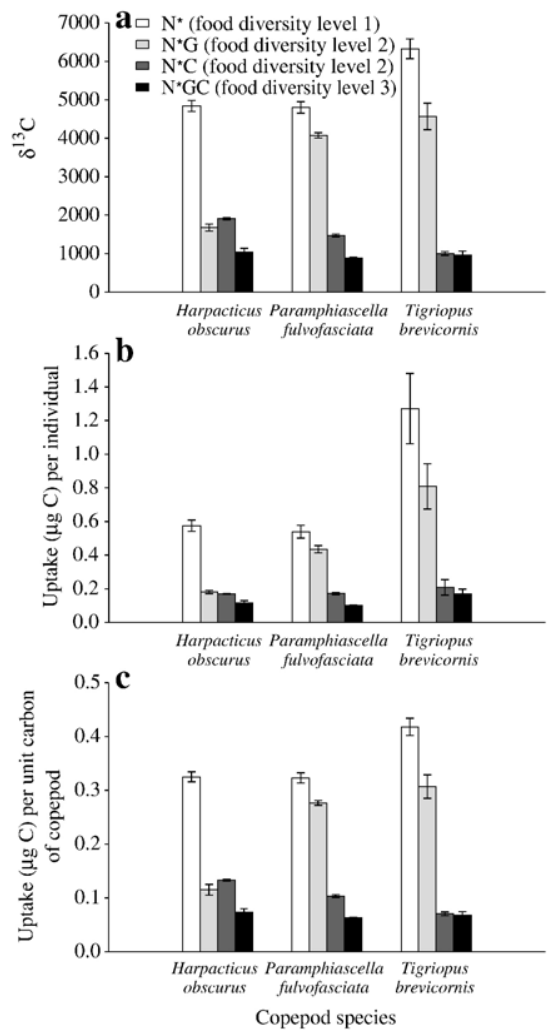

Uptake Grammatophora marina
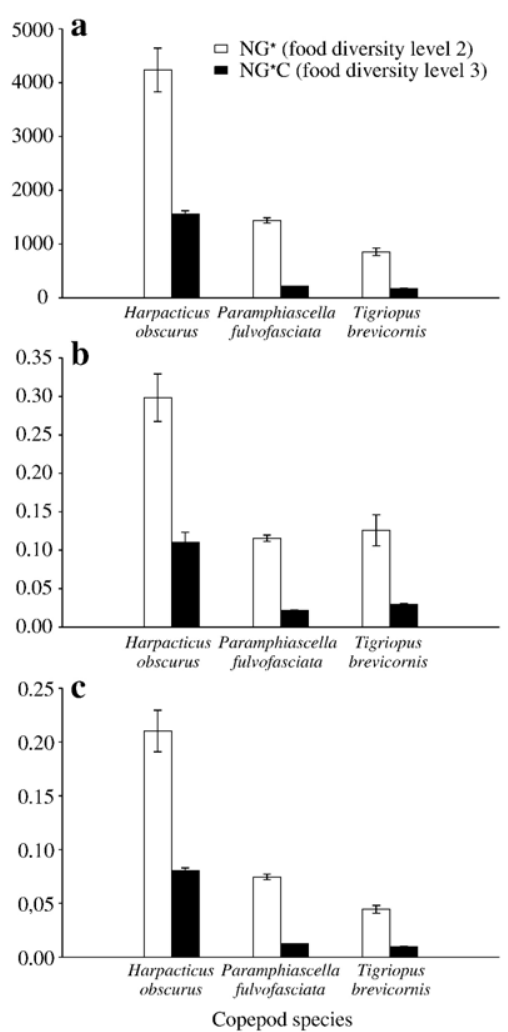

Uptake Cylindrotheca closterium
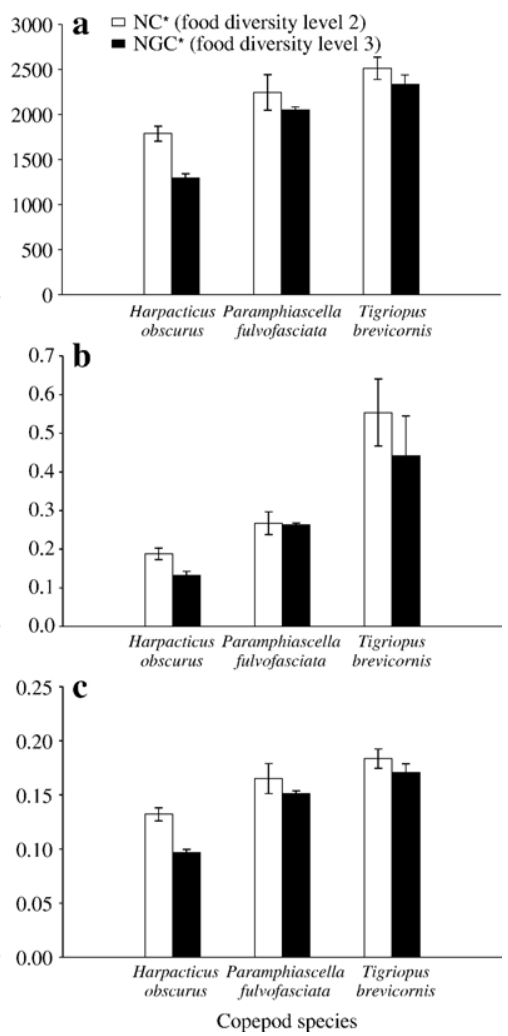

Fig. 2. Uptake of the diatoms Navicula phyllepta, Grammatophora marina and Cylindrotheca closterium in treatments with different levels of food diversity, expressed as (a) $\delta^{13} \mathrm{C}$, (b) uptake per individual relative to copepod biomass and (c) uptake per unit carbon of copepod. (N=Navicula phyllepta, $\mathrm{G}=$ Grammatophora marina, $\mathrm{C}=$ Cylindrotheca closterium, $*={ }^{13} \mathrm{C}$-labeled).

species. The experiment was designed with special interest for the uptake of $N$. phyllepta. Therefore and because of limited material of copepods, the following treatments were not included: monocultures of the two other diatoms $\left(\mathrm{G}^{*}, \mathrm{C}^{*}\right), \mathrm{G}^{*} \mathrm{C}$ and $\mathrm{GC} *$. The applied food densities (Table 1) were based on counts of diatom cells in faecal pellets (De Troch and Ólafsson, unpublished) where it was estimated that 125,000 diatom cells/treatment would correspond to food limitation.

The experiment lasted $96 \mathrm{~h}$; afterwards, the experimental units were immediately frozen. Later on, the material was thawed, copepods were picked out of the Petri plates using a needle, washed several times in deionized-distilled water and transferred to tin capsules $(8 \times 5 \mathrm{~mm}$, Elemental Microanalysis Ltd., Devon, UK). The specimens were sorted within $2 \mathrm{~h}$ of thawing to minimize possible leakage of the label as suggested by e.g. Moens et al. (1999). Tin capsules containing copepods were then dried in an oven at $60{ }^{\circ} \mathrm{C}$ for at least $12 \mathrm{~h}$. Measurements of $\delta^{13} \mathrm{C}$ were done using an isotope ratio mass spectrometer (type Europa Integra) at the UC Davis Stable Isotope Facility (University of California, USA).

Delta ${ }^{13} \mathrm{C}$ values were standardised according to individual copepod biomass (Middelburg et al., 2000). Incorporation of ${ }^{13} \mathrm{C}$ is reflected as excess (above background) ${ }^{13} \mathrm{C}$ and expressed as uptake $(I)$ in $\mu \mathrm{g}{ }^{13} \mathrm{C}$ ind. $^{-1}$, calculated as the product of excess ${ }^{13} \mathrm{C}(\mathrm{E})$ and individual biomass (organic carbon). $E$ is the difference between the fraction ${ }^{13} \mathrm{C}$ at $T_{0}\left(F_{\text {initial }}\right)$ and the sample $\left(F_{\text {sample }}\right)$, where $F={ }^{13} \mathrm{C} /\left({ }^{13} \mathrm{C}+{ }^{12} \mathrm{C}\right)=R /(R+1)$. The carbon isotope ratio $(R)$ was derived from the measured $\delta^{13} \mathrm{C}$ values as $R=\left(\delta^{13} \mathrm{C} / 1000+1\right) \times R_{\mathrm{VPDB}}$ with $R_{\mathrm{VPDB}}=$ 0.0112372 as $\delta^{13} \mathrm{C}$ is expressed relative to Vienna Pee Dee Belemnite (VPDB). This uptake was then further standardized and expressed per unit carbon of copepod.

The amount of diatom carbon taken up by copepods, expressed both per individual and per unit carbon of copepod, was further standardized taking into account the proportion of ${ }^{13} \mathrm{C}$ in each diatom food source (see before) by multiplying the amount of diatom ${ }^{13} \mathrm{C}$ taken 
up by copepods with a factor derived from the atomic percentage ${ }^{13} \mathrm{C}$ of the diatom food source.

A two-way analyse of variance (ANOVA, Statistica 6.0 software, StatSoft Inc., 2001) was applied to test for differences in diatom uptake among treatments with variable food diversity and copepod species. Cochran's C-test was applied to test the assumption of homoscedascity. For diversity level 2 and 3 (= number of diatom species in a treatment) an additional ANOVA was done with an experimental design as follows: diversity levels as blocks and the different treatments (different diatom species) were nested into these blocks. Within the 'Experimental design' in Statistica 6.0 we selected the Central composite option as this can be used for full factorial designs or designs with unbalanced nesting.

\section{Results}

An increase in the level of food diversity significantly reduced the uptake of $N$. phyllepta by the graz- ers as was shown by a lower delta ${ }^{13} \mathrm{C}$ signal. For the uptake of $N$. phyllepta, all treatments were found to be significantly different from each other for all copepod species (Tukey HSD tests, all $p<0.0084$ ), except for $\mathrm{N}^{*} \mathrm{C}$ and $\mathrm{N}^{*} \mathrm{GC}$ in the case of T. brevicornis (Tukey HSD test, $p=0.99$ ) (Fig. 2a). The uptake of $C$. closterium was affected in the same way, though not significantly (Table 2, interaction effect). Standardization of diatom uptake per unit carbon of copepod (Fig. 2c) always showed the same patterns as the $\delta^{13} \mathrm{C}$ outcome (Fig. 2a).

The same species-specific patterns were observed for the diatom uptake expressed per individual. However, clear differences at an interspecific level (Fig. 2b) were found. T. brevicornis, the largest among the copepods, exhibited the highest amount of diatom carbon per individual (Tukey HSD tests and multiple comparisons, all $p<0.05$ ). Yet, H. obscurus took up the largest amount of $G$. marina carbon per individual (Fig. 2b). In the $\mathrm{N}^{*} \mathrm{C}$ and $\mathrm{N}^{*} \mathrm{GC}$ treatments, no differences in diatom uptake were found between the copepod species (Kruskal-

Table 2

Two-way ANOVA tests of significance of the effect of diversity of the food source (treatment), copepod species and their interaction on food selectivity

\begin{tabular}{|c|c|c|c|c|c|c|c|c|c|c|}
\hline \multicolumn{11}{|l|}{ Diversity } \\
\hline & \multirow{2}{*}{$\frac{\text { Error }}{d f}$} & \multicolumn{3}{|c|}{ Treatment } & \multicolumn{3}{|c|}{ Copepod species } & \multicolumn{3}{|c|}{ Treatment $\times$ Copepod species } \\
\hline & & $d f$ & $F$ & $p$ & $d f$ & $F$ & $p$ & $d f$ & $F$ & $p$ \\
\hline \multicolumn{11}{|l|}{ Uptake $N$. phyllepta } \\
\hline$\delta^{13} \mathrm{C}$ & 24 & 3 & 669,802 & $<0.0001$ & 2 & 13,917 & 0,0001 & 6 & 51,314 & $<0.0001$ \\
\hline per individual & $\mathrm{n} / \mathrm{a}$ & $\mathrm{n} / \mathrm{a}$ & $\mathrm{n} / \mathrm{a}$ & & $\mathrm{n} / \mathrm{a}$ & $\mathrm{n} / \mathrm{a}$ & $\mathrm{n} / \mathrm{a}$ & $\mathrm{n} / \mathrm{a}$ & $\mathrm{n} / \mathrm{a}$ & $\mathrm{n} / \mathrm{a}$ \\
\hline per unit carbon of copepod & 23 & 3 & 648,657 & $<\mathbf{0 . 0 0 0 1}$ & 2 & 12,480 & 0,0002 & 6 & 44,071 & $<\mathbf{0 . 0 0 0 1}$ \\
\hline \multicolumn{11}{|l|}{ Uptake $G$. marina } \\
\hline$\delta^{13} \mathrm{C}$ & $\mathrm{n} / \mathrm{a}$ & $\mathrm{n} / \mathrm{a}$ & $\mathrm{n} / \mathrm{a}$ & $\mathrm{n} / \mathrm{a}$ & $\mathrm{n} / \mathrm{a}$ & $\mathrm{n} / \mathrm{a}$ & $\mathrm{n} / \mathrm{a}$ & $\mathrm{n} / \mathrm{a}$ & $\mathrm{n} / \mathrm{a}$ & $\mathrm{n} / \mathrm{a}$ \\
\hline per individual & 12 & 1 & 216,356 & $<\mathbf{0 . 0 0 0 1}$ & 2 & 79,442 & $<\mathbf{0 . 0 0 0 1}$ & 2 & 0,801 & 0,47 \\
\hline per unit carbon of copepod & 12 & 1 & 570,195 & $<\mathbf{0 . 0 0 0 1}$ & 2 & 400,660 & $<\mathbf{0 . 0 0 0 1}$ & 2 & 4,972 & 0,0267 \\
\hline \multicolumn{11}{|l|}{ Uptake $C$. closterium } \\
\hline$\delta^{13} \mathrm{C}$ & 12 & 1 & 9,980 & 0,0082 & 2 & 32,333 & $<\mathbf{0 . 0 0 0 1}$ & 2 & 1,210 & 0,33 \\
\hline per individual & 12 & 1 & 2,698 & 0,13 & 2 & 28,485 & $<\mathbf{0 . 0 0 0 1}$ & 2 & 0,635 & 0,55 \\
\hline per unit carbon of copepod & 12 & 1 & 9,955 & $\mathbf{0 , 0 0 8 3}$ & 2 & 32,042 & $<\mathbf{0 . 0 0 0 1}$ & 2 & 1,254 & 0,32 \\
\hline \multicolumn{11}{|l|}{ Identity } \\
\hline & \multirow{2}{*}{$\frac{\text { Error }}{d f}$} & \multicolumn{3}{|c|}{ Treatment } & \multicolumn{3}{|c|}{ Copepod species } & \multicolumn{3}{|c|}{ Treatment $\times$ Copepod species } \\
\hline & & $d f$ & $F$ & $p$ & $d f$ & $F$ & $p$ & $d f$ & $F$ & $p$ \\
\hline \multicolumn{11}{|l|}{ Food diversity level 2} \\
\hline$\delta^{13} \mathrm{C}$ & 24 & 3 & 94,731 & $<\mathbf{0 . 0 0 0 1}$ & 2 & 9,449 & 0,0009 & 6 & 94,280 & $<0.0001$ \\
\hline per individual & $\mathrm{n} / \mathrm{a}$ & & & & & & & & & \\
\hline per unit carbon of copepod & 23 & 3 & 129,506 & $<\mathbf{0 . 0 0 0 1}$ & 2 & 7,405 & $\mathbf{0 , 0 0 3 3}$ & 6 & 81,00 & $<\mathbf{0 . 0 0 0 1}$ \\
\hline \multicolumn{11}{|l|}{ Food diversity level 3} \\
\hline$\delta^{13} \mathrm{C}$ & $\mathrm{n} / \mathrm{a}$ & $\mathrm{n} / \mathrm{a}$ & $\mathrm{n} / \mathrm{a}$ & $\mathrm{n} / \mathrm{a}$ & $\mathrm{n} / \mathrm{a}$ & $\mathrm{n} / \mathrm{a}$ & $\mathrm{n} / \mathrm{a}$ & $\mathrm{n} / \mathrm{a}$ & $\mathrm{n} / \mathrm{a}$ & $\mathrm{n} / \mathrm{a}$ \\
\hline per individual & $\mathrm{n} / \mathrm{a}$ & $\mathrm{n} / \mathrm{a}$ & $\mathrm{n} / \mathrm{a}$ & $\mathrm{n} / \mathrm{a}$ & $\mathrm{n} / \mathrm{a}$ & $\mathrm{n} / \mathrm{a}$ & $\mathrm{n} / \mathrm{a}$ & $\mathrm{n} / \mathrm{a}$ & $\mathrm{n} / \mathrm{a}$ & $\mathrm{n} / \mathrm{a}$ \\
\hline per unit carbon of copepod & 18 & 2 & 706,677 & $<\mathbf{0 . 0 0 0 1}$ & 2 & 49,713 & $<0.0001$ & 4 & 145,363 & $<\mathbf{0 . 0 0 0 1}$ \\
\hline
\end{tabular}

Significant parameters are indicated in bold.

Effect of identity of the food was tested by blocking it within each food diversity level. (n/a, assumptions for ANOVA not met). 

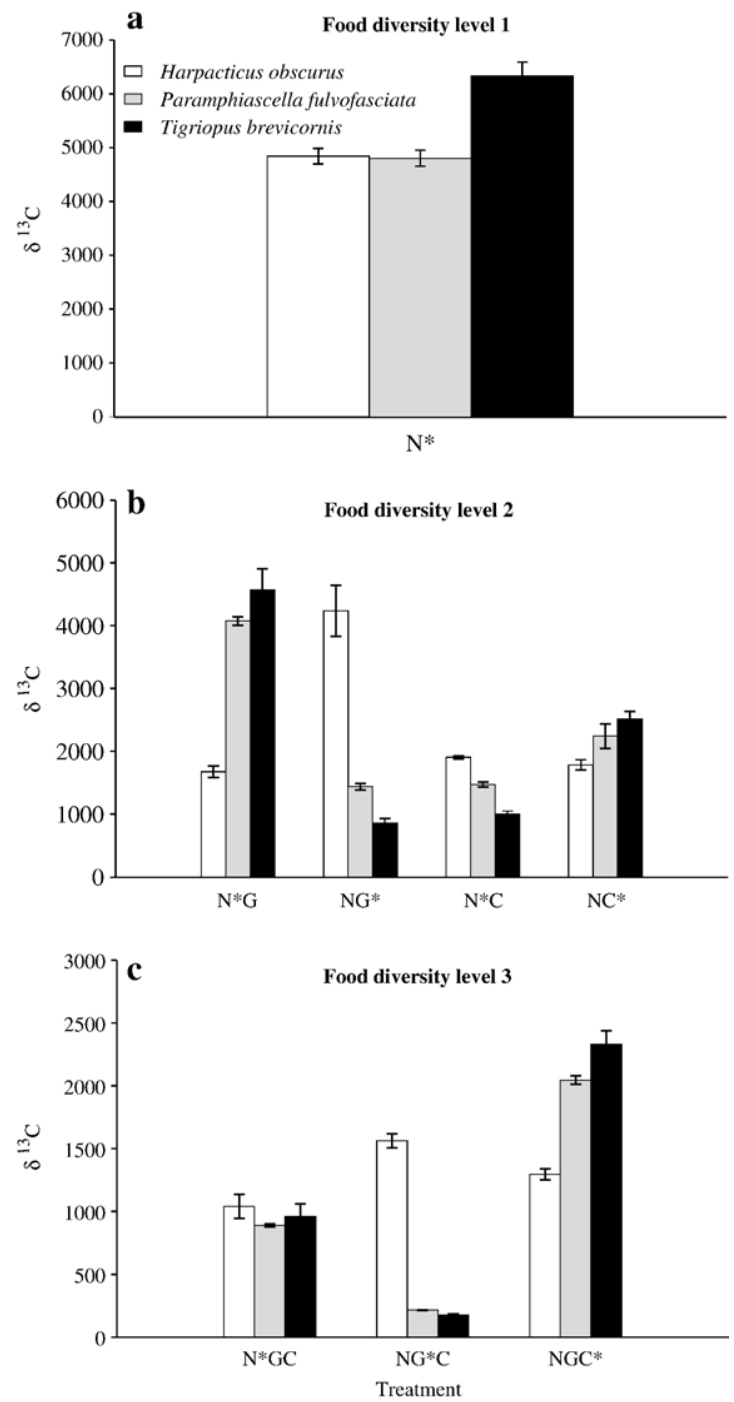

Fig. 3. Diatom uptake (mean $\pm \mathrm{SE}$ ), expressed as $\delta^{13} \mathrm{C}$, by 3 harpacticoid copepods in the three diversity levels. $(\mathrm{N}=$ Navicula phyllepta, $\mathrm{G}=$ Grammatophora marina, $\mathrm{C}=$ Cylindrotheca closterium, $*={ }^{13}$ C-labeled).

Wallis test: $d f=2, N=9, \mathrm{~N}^{*} \mathrm{C}: H=6.22$ and $p=0.73$, $\mathrm{N}^{*} \mathrm{GC}: H=3.82$ and $p=0.15$ ).

In addition, treatments (different diatom species) were nested into blocks corresponding to diversity level 2 or 3 (= number of diatom species in a treatment). Overall, these blocks were significantly different from each other $(p<0.1)$ with diatom species identity being the most important factor $(p<0.001)$.

At food diversity level 1 (Fig. 3a), significant differences in the uptake of $N$. phyllepta exist between the copepod species. Whereas uptake of $N$. phyllepta was the same for H. obscurus and P. fulvofasciata (Tukey HSD test, $p=0.99)$, it was significantly higher for
T. brevicornis (Tukey HSD tests, both $p<0.004$ ). When diatom uptake was expressed per individual (not shown), this interspecific difference was even more pronounced.

At food diversity level 2 (Fig. 3b), copepod speciesspecific diatom uptake (expressed as $\delta^{13} \mathrm{C}$ ) varied clearly between all 2-diatoms treatments with the identity of the diatom species in the composed diet being of major importance. The uptake of $N$. phyllepta (expressed as $\delta^{13} \mathrm{C}$ ) tended to vary depending on whether it was offered in combination with G. marina $\left(\mathrm{N}^{*} \mathrm{G}\right)$ or $C$. closterium $\left(\mathrm{N}^{*} \mathrm{C}\right)$, but there was a clear species-specific response. The uptake of $N$. phyllepta by $P$. fulvofasciata and T. brevicornis was significantly lower when it was offered in combination with $C$. closterium than with $G$. marina (treatments $\mathrm{N}^{*} \mathrm{C}$ and $\mathrm{N}^{*} \mathrm{G}$, Tukey HSD tests, both $p=0.0002$ ). In the diet combining $N$. phyllepta and G. marina, $H$ obscurus took up much more G. marina, whereas $P$. fulvofasciata and $T$. brevicornis selected $N$. phyllepta. When $N$. phyllepta and C. closterium were offered together, P. fulvofasciata and $T$. brevicornis took up more $C$. closterium (Tukey HSD tests, both $p<0.0047)$. H. obscurus, however, took up both the diatoms equally (Tukey HSD test, $p=0.90$ ).

Diatom uptake per individual (not shown) yielded the same species-specific patterns as the ones reported for $\delta^{13} \mathrm{C}$. T. brevicornis took up the highest amount of $N$. phyllepta (treatment $\mathrm{N}^{*} \mathrm{G}$ ) and C. closterium (treatment $\left.\mathrm{NC}^{*}\right)$ per individual. $H$. obscurus took up the highest amount of $G$. marina per individual (treatment $\mathrm{NG}^{*}$ ).

At food diversity level 3 (Fig. 3c), again a clear preference for G. marina was measured for H. obscurus. P. fulvofasciata and T. brevicornis on the other hand took up a large amount of carbon from C. closterium.

Diatom uptake per individual (not shown) exhibited similar intraspecific patterns for P. fulvofasciata and T. brevicornis. For H. obscurus, diatom uptake per individual was the same for the 3 diatoms. Further, $H$. obscurus took up the highest amount of G. marina, whereas $T$. brevicornis took up the highest amount of C. closterium.

\section{Discussion}

As illustrated in previous studies, ecosystem processes can be influenced by the diversity of trophically basal species via trophic interactions (Tilman et al., 1997a; Loreau and Hector, 2001; Hooper et al., 2005). Here, it was shown that next to diversity of primary producers (how many food types are available) also their identity (what kind of food types are available) has an important 
effect on food choice of harpacticoid copepods as marine grazers. In general, all harpacticoids took up a smaller amount of a single food species as food diversity increased. This logical outcome is of course linked to the fact that a higher diversity implied a higher resource availability since total biomass was not kept constant among treatments (individual diatom biomass were added up in higher diversity treatments). Whereas all consumers reacted similarly to changing food diversity, strong species-specific responses of the grazers to food identity were found. Different copepods selected different food sources when offered the choice.

Different techniques have been used in previous studies to quantify food selectivity. For example, preference indices have been established to relate the uptake of certain food resources to food availability in the environment. These indices could partly help to overcome the drawback of increased amount of resources in higher diversity treatments in the present study. However, we opted to use the more recent technique of stable isotopes to trace food uptake but this technique does not take into account the differential digestion of prey since it measures the actual amount of assimilated carbon from a certain food source. Therefore, it is not appropriate to use indices of food preference in stable isotope tracing studies. Moreover, several shortcomings of preference indices were reported before (e.g. Strauss, 1979). He stated that inadequate habitat sampling (in the present study: good estimation of initial number of diatom cells), differential availability of prey to the predator (in present study: different diatom concentrations), and differential digestion of prey (unknown for copepods so far) may be significant sources of error in the interpretation of food selection data by means of preference indices.

Food selection may also differ between artificial versus natural conditions (Pace and Carman, 1996). Factors such as the absence of specific substrata, the controlled temperature, comparatively low grazer densities and the availability of sufficient food in the present experiment may all restrict the possibility of extrapolating the outcome to natural situations. In addition, the availability of diatoms for harpacticoid copepods may vary strongly in the field. Moreover, alternative food sources (e.g. bacteria, detritus) were not taken into account in the present study; experimental units were detritus-free but non-axenic. Nevertheless, small-scale microcosm experiments can suggest hypotheses and mechanisms that can be tested in longerterm field experiments.

In the frame of studies on the effects of biodiversity on trophic transfer, the present experiment contributes considerably as food diversity was manipulated directly and the effects of diversity and identity changes within a trophic level (primary producers) on another trophic level (primary consumers) were evaluated from a 'bottom-up' point of view i.e. the diversity and identity of the food source was manipulated. However, the reader should note that the reported effect of diversity in the present study is inevitably linked to a possible effect of resource availability. In addition, there was no food limitation in any of the treatments, so food choice may also depend on food concentration (see also De Troch et al., 2007).

According to Hillebrand and Cardinale (2004), diverse prey assemblages are generally less vulnerable to consumption. The outcome of the present experiment indeed shows that uptake of a particular food species decreases with increasing food diversity (and concomitant increasing food availability). The same overall pattern is found for all consumer species in the present study, suggesting that harpacticoids switch diet or mix different foods when the choice is offered. Moreover, the obtained results agree with those of Steiner (2001), who found that increased phytoplankton species richness resulted in lower total consumption. This pattern thus seems to apply to both benthic (present study) and planktonic (Steiner, 2001) marine grazers.

More diverse systems have a higher probability of containing a particular species with important traits influencing ecosystem function, the "sampling effect" (Huston, 1997; Tilman et al., 1997b). This trait may be a limiting nutrient or trace-element. A consumer is assumed to choose the diet which maximizes net energy intake (Hughes, 1980) and must therefore choose among prey of different nutritional values. These choices can be crucial for herbivores because they rely on prey that are critically low in protein compared to what is needed to produce animal biomass (Mattson, 1980; White, 1993). The availability of an extra prey species may thus further enrich an already nutritious diet (Kleppel and Burkart, 1995; Schmidt and Jonasdottir, 1997). Some consumers therefore actively mix different foods to achieve a more balanced diet (Pennings et al., 1993; Bernays et al., 1994). If various foods are sources of different limiting nutrients (i.e. complementary resources, sensu Tilman, 1988), consumers might survive on only one or another, but would perform better on some mixture. In some animals, however, there is evidence of cognitive overload even with very few options, with the consequence of decreased consumption and performance. Problems may arise in recalling how to deal quickly with each option or in making good decisions based on identity or quality of the options (Hutchinson, 2005). 
On the other hand, more diverse food assemblages, due to the sampling effect, also have a higher chance of containing less edible species (Duffy, 2002). The presence of non-edible prey is generally expected to reduce the efficiency of predator-prey interactions (Grover, 1995; Steiner, 2003). Since even at the experimental diversity level 3 all three diatom species were consumed, this mechanism apparently is not applicable here.

This lab experiment point to an effect of diversity (and concomitant food availability) on food uptake. Harpacticoids mix different foods, resulting in lower consumption of one particular food source. Nevertheless, the dual interpretation of the sampling effect illustrates the importance of food identity.

Bruno et al. (2005) noted that species identity generally appears to be much more important than species richness in controlling primary biomass production in a benthic marine community. Here some evidence of an effect of primary producers' identity on food selection by marine grazers is provided, hence influencing energy transfer to higher trophic levels. All food species in the conducted experiment were consumed, although not all to the same extent. Moreover, within the same level of food diversity, harpacticoids showed a speciesspecific preference for one or another diatom species. P. fulvofasciata and T. brevicornis fed preferentially on C. closterium, whereas $H$. obscurus on G. marina. H. obscurus may thus be suggested to profit from its ability to feed on aggregated cells (i.e. ingest many cells all at once). In periods of extensive diatom blooms, for instance, this copepod species may have an advantage in comparison with species that need to pick up food items one by one.

It has been illustrated by various authors that a preference for one option over another can be reversed when a third option is added (e.g. Bateson et al., 2002; Shafir et al., 2002) and the results obtained here are in close agreement with these findings. In absence of their preferential food (i.e. C. closterium), P. fulvofasciata and T. brevicornis showed an albeit negative (sensu Underwood et al., 2004) preference for $N$. phyllepta. $H$. obscurus, in contrast, did not show any preference for $N$. phyllepta or C. closterium when its preferential food (i.e. G. marina) is not available. These two prey species have apparently the same value for H. obscurus. Overall, however, different primary producers do not seem to be equivalent, and thus not redundant, as a food source for harpacticoids.

Describing the functional relationship between consumers and their food suffers from considerable confusion. Singer (2000) has therefore proposed 3 components to specify the process of food choice: (1) preference, for choices made by consumers, (2) acceptability, for properties (identity, quality) of the food, and (3) electivity, for the properties of the interaction between the consumer and its food. Based on their different sizes, shapes and life forms (including colonial vs. single-celled), the three diatoms used in the present study were expected to differ in their acceptability. The recognition of and response to differences in identity or quality of food sources is crucial for consumers that mix different foods, as harpacticoids do. A recent study (De Troch et al., 2006) showed an effect of food particle size on food selection in different harpacticoid copepod species. In addition, copepods were illustrated to be able to discriminate between similar-sized food particles in accordance with their chemical properties ('taste', DeMott, 1988).

In the present study, food identity or acceptability were only considered in terms of size and shape (i.e. external features of the food). Yet, aquaculture research has shown that marine fish and invertebrates are sensitive to a host of food qualities (i.e. internal features) including the relative proportions of protein, carbohydrate and lipid, the amino acid composition of the protein, the lipid composition and the presence of vitamins and minerals (e.g. McEvoy et al., 1998; Shiau, 1998). Any of these factors could vary between algae, both inter- and intraspecifically (e.g. because of different growth conditions, Wen and Chen, 2003), and thus might also influence food choice.

It became increasingly obvious that even in lower marine food webs, neither consumers nor food items are functionally redundant, supporting the idea of CruzRivera and Hay (2000), who argued that small marine consumers should no longer be pooled into functional groups whose members are assumed to have similar nutritional needs and feeding capabilities. Taking into account the important role of harpacticoid copepods as a link between microalgal primary producers and higher trophic levels, these findings may have implications concerning the impact of species loss for trophic transfer. Diversity is both important at higher trophic levels and at the foundation of the food pyramid. To further unravel the role of diversity and identity in lower food webs, a series of obvious options is now open for future investigation e.g. to test the effects on consumer fitness and its population dynamics and consider the importance of food quality for trophic interactions.

\section{Acknowledgements}

M.D.T. is a post-doctoral fellow with the Fund for Scientific Research (FWO-Flanders). This study was 
conducted within the frame of FWO research project G.0313.04. Additional financial support was received from GOA 01GZ0705 (BOF-Ghent University). [SS]

\section{References}

Aberle, N., Hillebrand, H., Grey, J., Wiltshire, K.H., 2005. Selectivity and competitive interactions between two invertebrate grazers (Asellus aquaticus and Potamopyrgus antipodarum): an experimental study using ${ }^{13} \mathrm{C}$ - and ${ }^{15} \mathrm{~N}$-labeled diatoms. Freshw. Biol. 50, 369-379.

Andersen, B.S., Carl, J.D., Grønkjær, P., Støttrup, J.G., 2005. Feeding ecology and growth of age 0 year Platichthys flesus (L.) in a vegetated an a bare sand habitat in a nutrient rich fjord. J. Fish Biol. $66,531-552$.

Bateson, M., Healy, S.D., Hurly, T.A., 2002. Irrational choices of hummingbird foraging behaviour. Anim. Behav. 63, 587-596.

Bernays, E.A., Bright, K.L., Gonzalez, N., Angel, J., 1994. Dietary mixing in a generalist herbivore: tests of two hypotheses. Ecology 75, 1997-2006.

Bruno, J.F., Boyer, K.E., Duffy, J.E., Lee, S.C., Kertesz, J.S., 2005. Effects of macroalgal species identity and richness on primary production in benthic marine communities. Ecol. Lett. 8, $1165-1174$.

Buffan-Dubau, E., Carman, K.R., 2000. Diel feeding behavior of meiofauna and their relationships with microalgal resources. Limnol. Oceanogr. 45, 381-395.

Carman, K.R., Thistle, D., 1985. Microbial food partitioning by three species of benthic copepods. Mar. Biol. 88, 143-148.

Charnov, E.L., 1976. Optimal foraging: attack strategy of a mantid. Am. Nat. 110, 141-151.

Coull, B.C., 1990. Are members of the meiofauna food for higher trophic levels? Trans. Am. Microsc. Soc. 109, 233-246.

Cruz-Rivera, E., Hay, M.E., 2000. Can quantity replace quality? Food choice, compensatory feeding and fitness of marine mesograzers. Ecology 81, 201-219.

De Troch, M., Mees, J., Wakwabi, E., 1998. Diets of abundant fishes from beach seine catches in seagrass beds of a tropical bay (Gazi Bay, Kenya). Belg. J. Zool. 128, 135-154.

De Troch, M., Chepurnov, V., Gheerardyn, H., Vanreusel, A., Ólafsson, E., 2006. Is diatom size selection by harpacticoid copepods related to grazer body size? J. Exp. Mar. Biol. Ecol. 332, 1-11.

De Troch, M., Grego, M., Chepurnov, V.A., Vincx, M., 2007. Food patch size, food concentration and grazing efficiency of the harpacticoid Paramphiascella fulvofasciata (Crustacea, Copepoda)? J. Exp. Mar. Biol. Ecol. 343, 210-216.

Decho, A.W., 1986. Water-cover influences on diatom ingestion rates by meiobenthic copepods. Mar. Ecol. Prog. Ser. 33, 139-146.

DeMott, W.R., 1988. Discrimination between algae and artificial particles by freshwater and marine copepods. Limnol. Oceanogr. 33, 397-408.

DeMott, W.R., 1989. Utilization of a cyanobacterium and a phosphorusdeficient green algae as complementary resources by daphnids. Ecology 79, 2463-2481.

Duffy, J.E., 2002. Biodiversity and ecosystem function: the consumer connection. Oikos 99, 201-219.

Gee, J.M., 1989. An ecological economic review of meiofauna as food for fish. Zool. J. Linn. Soc. 96, 243-261.

Goecker, M.E., Kåll, S.E., 2003. Grazing preferences of marine isopods and amphipods on three prominent algal species of the Baltic Sea. J. Sea Res. 50, 309-314.
Grover, J.P., 1995. Competition, herbivory and enrichment: nutrientbased models for edible and inedible plants. Am. Nat. 145, 746-774.

Guillard, R.L., 1975. Culture of phytoplankton for feeding marine invertebrates. In: Smith, W.L., Chandley, M.H. (Eds.), Culture of Marine Invertebrate Animals. Plenum Press, New York, pp. 29-60.

Hicks, G.R.F., Coull, B.C., 1983. The ecology of marine meiobenthic harpacticoid copepods. Oceanogr. Mar. Biol. Annu. Rev. 21, 67-175.

Hillebrand, H., Cardinale, B.J., 2004. Consumer effects decline with prey diversity. Ecol. Lett. 7, 192-201.

Hillebrand, H., Dürselen, C.-D., Kirschtel, D., Pollingher, U., Zohary, T., 1999. Biovolume calculation for pelagic and benthic microalgae. J. Phycol. 35, 403-424.

Hooper, D.U., Chapin, F.S., Ewel, J.J., Hector, A., Inchausti, P., Lavorel, S., Lawton, J.H., Lodge, D.M., Loreau, M., Naeem, S., Schmid, B., Setälä, H., Symstad, A.J., Vandermeer, J., Wardle, D.A., 2005. Effects of biodiversity on ecosystem functioning: a consensus of current knowledge. Ecol. Monogr. 75, 3-35.

Hughes, R.N., 1980. Optimal foraging theory in the marine context. Oceanogr. Mar. Biol. Annu. Rev. 18, 423-481.

Huston, M.A., 1997. Hidden treatments in ecological experiments: reevaluating the ecosystem function of biodiversity. Oecologia 110 , 449-460.

Hutchinson, J.M.C., 2005. Is more choice always desirable? Evidence and arguments from leks, food selection and environmental enrichment. Biol. Rev. 80, 73-92.

Irigoien, W., Head, R.N., Harris, R.P., Cummings, D., Harbour, D., MeyerHarms, B., 2000. Feeding selectivity and egg production of Calanus helgolandicus in the English Channel. Limnol. Oceanogr. 45, 44-54.

Kiorboe, T., Saiz, E., Viitasalo, M., 1996. Prey switching behavior in the planktonic copepod Acartia tonsa. Mar. Ecol. Prog. Ser. 143, 65-75.

Kleppel, G.S., Burkart, C.A., 1995. Egg-production and the nutritional environment of Acartia tonsa: the role of food quality in copepod nutrition. ICES J. Mar. Sci. 52, 297-304.

Loreau, M., Hector, A., 2001. Partitioning selection and complementarity in biodiversity experiments. Nature $412,72-76$.

Mattson Jr., W.J., 1980. Herbivory in relation to plant nitrogen content. Ann. Rev. Ecolog. Syst. 11, 119-161.

McEvoy, L.A., Naess, T., Bell, J.G., Lie, O., 1998. Lipid and fatty acid composition of normal and malpigmented Atlantic halibut (Hippoglossus hippoglossus) fed enriched Artemia: a comparison with fry fed wild copepods. Aquaculture 163, 237-250.

Middelburg, J.J., Barranguet, C., Boschker, H.T.S., Herman, P.T., Moens, T., Heip, C.H.R., 2000. The fate of intertidal microphytobenthos carbon: An in situ ${ }^{13} \mathrm{C}$-labeling study. Limnol. Oceanogr. 45, $1224-1234$

Moens, T., Verbeeck, L., Vincx, M., 1999. Preservation and incubation time-induced bias in tracer-aided grazing studies on meiofauna. Mar. Biol. 133, 69-77.

Montagna, P.A., 1995. Rates of metazoan meiofaunal microbivory: a review. Vie Milieu 45, 1-9.

Nilsson, P., 1987. Demography of Mesochra lilljeborgi and Amonardia normani (Copepoda, Harpacticoida) reared on 2 diatom diets. Mar. Ecol. Prog. Ser. 39, 267-274.

Pace, M.C., Carman, K.R., 1996. Interspecific differences among meiobenthic copepods in the use of microalgal food resources. Mar. Ecol. Prog. Ser. 143, 77-86.

Pennings, S.C., Masatomo, T.N., Paul, V.J., 1993. Selectivity and growth of the generalist herbivore Dolabella auricularia feeding upon complementary resources. Ecology $74,879-890$.

Rieper, M., 1982. Feeding preferences of marine harpacticoid copepods for various species of bacteria. Mar. Ecol. Prog. Ser. 7, 303-307. 
Schmidt, K., Jonasdottir, S.H., 1997. Nutritional quality of two cyanobacteria: how rich is 'poor' food? Mar. Ecol. Prog. Ser. 151, $1-10$.

Sellner, B.W., 1976. Survival and metabolism of the harpacticoid copepod Thompsonula hyaenae (Thompson) fed on different diatoms. Hydrobiologia 50, 233-238.

Shafir, S., Waite, T.A., Smith, B.H., 2002. Context-dependent violations of rational choice in honeybees (Apis mellifera) and gray jays (Perisoreus canadensis). Behav. Ecol. Sociobiol. 51, $180-187$.

Shiau, S.-Y., 1998. Nutrient requirements of penaeid shrimps. Aquaculture 164, 77-93.

Singer, M.C., 2000. Reducing ambiguity in describing plant-insect interactions: 'preference', 'acceptability' and 'electivity'. Ecol. Lett. $3,159-162$.

Sommer, F., Stibor, H., Sommer, U., Velimirov, B., 2000. Grazing by mesozooplankton from Kiel Bight, Baltic Sea, on different sized algae and natural seston size fractions. Mar. Ecol. Prog. Ser. 199, 43-53.

Steiner, C.F., 2001. The effects of prey heterogeneity and consumer identity on the limitation of trophic-level biomass. Ecology 82, 2495-2506.

Steiner, C.F., 2003. Keystone predator effects and grazer control of planktonic primary production. Oikos 101, 569-577.

Stephens, D.W., Krebs, J.R., 1986. Foraging Theory. Princeton University Press, Princeton.

Strauss, R.E., 1979. Reliability estimates for Ivlev's electivity index, the forage ratio, and a proposed linear index of food selection. Trans. Am. Fish. Soc. 108, 344-352.
Tackx, M.L.M., Herman, P.J.M., Gasparini, S., Irigoien, X., Billiones, R., Daro, M.H., 2003. Selective feeding of Eurytemora affinis (Copepoda, Calanoida) in temperate estuaries: model and field observations. Estuar. Coast. Shelf Sci. 56, 305-311.

Tilman, D., 1988. Plant Strategies and the Dynamics and Structure of Plant Communities. Monographs in Population Biology, vol. 26. Princeton University Press, Princeton.

Tilman, D., Knops, J., Wedin, D., Reich, P., Ritchie, M., Siemann, E., 1997a. The influence of functional diversity and composition on ecosystem processes. Science 277, 1300-1302.

Tilman, D., Lehman, C.L., Thomson, K.T., 1997b. Plant diversity and ecosystem productivity: theoretical considerations. Proc. Natl. Acad. Sci. U. S. A. 94, 1857-1861.

Turner, J.T., 2004. The importance of small planktonic copepods and their roles in pelagic marine food webs. Zool. Stud. 43, 255-266.

Underwood, A.J., Chapman, M.G., Crowe, T.P., 2004. Identifying and understanding ecological preferences for habitat or prey. J. Exp. Mar. Biol. Ecol. 300, 161-187.

Vanden Berghe, W., Bergmans, M., 1981. Differential food preferences in three co-occurring species of Tisbe (Copepoda, Harpacticoida). Mar. Ecol. Prog. Ser. 4, 213-219.

Wainwright, P.C., 1994. Functional morphology as a tool in ecological research. In: Wainwright, P.C., Reilly, S.M. (Eds.), Ecological Morphology: Integrative Organismal Biology. University of Chicago Press, Chicago, pp. 42-59.

Wen, Z.Y., Chen, F., 2003. Heterotrophic production of eicosapentaenoic acid by microalgae. Biotechnol. Adv. 21, 273-294.

White, T.C.R., 1993. The Inadequate Environment: Nitrogen and the Abundance of Animals. Springer-Verlag, New York. 